\title{
Low interleukin-2 concentration favors generation of early memory $T$ cells over effector phenotypes during chimeric antigen receptor T-cell expansion
}

Kaartinen, Tanja

2017-06

Kaartinen , T , Luostarinen, A , Maliniemi , P , Keto , J , Arvas , M , Belt , H , Koponen , J , Loskog, A, Mustjoki , S , Porkka, K, Yla-Herttuala, S \& Korhonen, M 2017 , ' Low interleukin-2 concentration favors generation of early memory $T$ cells over effector phenotypes during chimeric antigen receptor T-cell expansion ' , Cytotherapy , vol. 19 , no. 6 , pp. 689-702 . https://doi.org/10.1016/j.jcyt.2017.03.067

http://hdl.handle.net/10138/198894

https://doi.org/10.1016/j.jcyt.2017.03.067

cc_by

publishedVersion

Downloaded from Helda, University of Helsinki institutional repository.

This is an electronic reprint of the original article.

This reprint may differ from the original in pagination and typographic detail.

Please cite the original version. 


\title{
Low interleukin-2 concentration favors generation of early memory $T$ cells over effector phenotypes during chimeric antigen receptor T-cell expansion
}

\author{
TANJA KAARTINEN ${ }^{1}$, ANNU LUOSTARINEN ${ }^{1}$, PILVI MALINIEMI ${ }^{1,2}$, JONI KETO ${ }^{2}$, \\ MIKKO ARVAS ${ }^{2}$, HEINI BELT ${ }^{3}$, JONNA KOPONEN ${ }^{3}$, ANGELICA LOSKOG ${ }^{4}$, \\ SATU MUSTJOKI ${ }^{5,6}$, KIMMO PORKKA $^{5}$, SEPPO YLÄ-HERTTUALA ${ }^{3,7}$ \& \\ MATTI KORHONEN ${ }^{1}$
}

${ }^{1}$ Advanced Cell Therapy Centre, Finnish Red Cross Blood Service, Helsinki, Finland, ${ }^{2}$ Research E Development, Finnish Red Cross Blood Service, Helsinki, Finland, ${ }^{3}$ Department of Biotechnology and Molecular Medicine, A.I. Virtanen Institute for Molecular Sciences, University of Eastern Finland, Kuopio, Finland, ${ }^{4}$ Department of Immunology, Genetics and Pathology, Science for Life Laboratory, Uppsala University, Uppsala, Sweden, ${ }^{5}$ Hematology Research Unit Helsinki, Biomedicum Helsinki, Department of Medicine, Division of Hematology, University of Helsinki, Helsinki, Finland, ${ }^{6}$ Department of Clinical Chemistry and Hematology, University of Helsinki, Helsinki, Finland, and ${ }^{7}$ Heart Center, Kuopio University Hospital, Kuopio, Finland

\begin{abstract}
Background. Adoptive T-cell therapy offers new options for cancer treatment. Clinical results suggest that T-cell persistence, depending on T-cell memory, improves efficacy. The use of interleukin (IL)-2 for in vitro T-cell expansion is not straightforward because it drives effector T-cell differentiation but does not promote the formation of T-cell memory. We have developed a cost-effective expansion protocol for chimeric antigen receptor (CAR) T cells with an early memory phenotype. Methods. Lymphocytes were transduced with third-generation lentiviral vectors and expanded using CD3/CD28 microbeads. The effects of altering the IL-2 supplementation (0-300 IU/mL) and length of expansion (10-20 days) on the phenotype of the T-cell products were analyzed. Results. High IL-2 levels led to a decrease in overall generation of early memory $\mathrm{T}$ cells by both de-

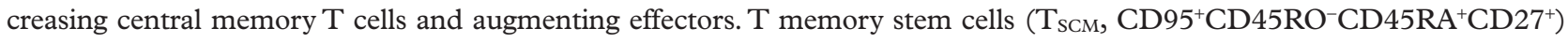
were present variably during T-cell expansion. However, their presence was not IL-2 dependent but was linked to expansion kinetics. CD19-CAR T cells generated in these conditions displayed in vitro antileukemic activity. In summary, production of CAR T cells without any cytokine supplementation yielded the highest proportion of early memory $\mathrm{T}$ cells, provided a 10fold cell expansion and the cells were functionally potent. Discussion. The number of early memory $\mathrm{T}$ cells in a T-cell preparation can be increased by simply reducing the amount of IL-2 and limiting the length of T-cell expansion, providing cells with potentially higher in vivo performance. These findings are significant for robust and cost-effective T-cell manufacturing.
\end{abstract}

Key Words: chimeric antigen receptor T cells, effector function, human, interleukin-2, T-cell expansion, T-cell memory

\section{Introduction}

Adoptive T-cell therapy, the administration of ex vivo processed $\mathrm{T}$ cells, provides new treatment options for refractory or advanced cancer [1]. Promising initial clinical results demonstrated in melanoma with tumorinfiltrating lymphocytes (TILs) [2] are now being followed by genetically engineered $\mathrm{T}$ cells. Use of T-cell receptor (TCR)-redirected T cells, e.g., in myeloma targeting NY-ESO-1 [3], and especially, the remarkable clinical success of chimeric antigen receptor (CAR) $\mathrm{T}$ cells in B-cell malignancies [4], justify the enthusiasm.

Nevertheless, clinical experience has shown that determining the in vivo potency of T-cell products for cancer is not straightforward. The durable control of cancer is not the result of a single cell population or a sole direct mechanism such as tumor cell killing. The

Correspondence: Tanja Kaartinen, MSc, Advanced Cell Therapy Centre, Finnish Red Cross Blood Service, Kivihaantie 7, 00310 Helsinki, Finland. E-mail:

Tanja.Kaartinen@bloodservice.fi 
durable control of cancer is rather due to a dynamic anti-tumor T-cell response entailing different cell types working in a temporally orchestrated manner during treatment and disease control. Furthermore, effector function, e.g., tumor cell killing, is connected to the short life expectancy on a per cell basis. Clinical results suggest that $\mathrm{T}$-cell persistence improves therapeutic response $[5,6]$ and this depends on telomere length [7] and development of immunologic memory [8-10].

Pre-clinical animal models have confirmed that memory $\mathrm{T}$ cells are pivotal for in vivo anti-tumor efficacy. Terminally differentiated effector $T$ cells with the most potent cytotoxic functionality are not the optimal therapeutic in the in vivo setting; instead, pure preparations of less-differentiated memory $T$ cells with greater in vivo proliferation and survival are more effective [11]. Thus, particular T-memory subsets with greater proliferative capacity should be pursued [11-14]: central memory $T$ cells $\left(\mathrm{T}_{\mathrm{CM}}\right)$ instead of effector memory ( $\mathrm{T}_{\mathrm{EM}}$, both defined in Sallusto et al. [15]), or even the most primitive $T$ memory stem cells ( $\mathrm{T}_{\mathrm{SCM}}$, defined in Gattinoni et al. [12]). $\mathrm{T}_{\mathrm{SCM}}$ provide not only superior potential for proliferation but also self-renewal.

Studies in cancer-targeting adoptive T-cell therapy have often focused solely on direct tumor cell killing potency [16]. However, there is increasing evidence for the importance of $\mathrm{CD} 4^{+}$cells in therapeutic T-cell products. $\mathrm{CD} 4^{+} \mathrm{T}$ cells may have several roles in cancer treatment provoking bystander immunity, supporting the activation of $\mathrm{CD}^{+}$cells as well as directly inhibiting tumor growth [17]. In the tumor milieu $\mathrm{CD}^{+}$cells have also shown to enhance the recruitment, proliferation and cytotoxic function of $\mathrm{CD}^{+}$cells [18]. Furthermore, in one clinical study T-cell persistence and clinical efficacy were associated with the presence of both less-differentiated $\mathrm{T}$ memory $\left(\mathrm{T}_{\mathrm{M}}\right)$ cells as well as $\mathrm{CD} 4^{+} \mathrm{T}$ cells in the cell product [10]. Interestingly, $\mathrm{CD} 4^{+}$cells are indispensable for functional $\mathrm{CD}^{+}$memory formation in mice $[19,20]$. It is not known if the indicated $\mathrm{CD} 4^{+}$importance for clinical efficacy was linked to memory formation.

In vivo, T-cell proliferation typically only takes place during an immune response and thus T-cell activation, proliferation and effector/memory differentiation are tightly coupled [21]. In vitro T-cell expansion is achieved with signals mimicking normal T-cell activation [1]. Signaling through CD3 and CD28 in vivo provokes autonomous IL- 2 production by the activated $\mathrm{T}$ cells, which is central to clonal expansion. Likewise, T-cell expansion in vitro is also characteristically boosted with interleukin (IL)-2, "the T-cell growth factor." However, IL-2 drives T cells toward effector differentiation at the expense of memory cell formation [21]. Both IL-2 signaling strength and du- ration are known to affect CD8 memory T-cell development [22]. Furthermore, excessive stimulation during in vitro expansion may lead to cell exhaustion [23], yielding less potent $T$ cells for therapy. Thus, generation of effective T-cell based cancer therapeutics requires a delicate balance between the final cell dose and the quality of the cells.

Currently, several approaches have been proposed for increasing the proportion of less-differentiated T cells. The replacement of IL- 2 with IL-7, IL-15 and IL-21 uses the concept of physiological homeostatic T-cell proliferation [24]. This favors early memory T-cell generation from normal donors [25-27] as well as from cancer patient-derived cells [28] and improves in vivo anti-tumor functionality in pre-clinical models $[11,29,30]$. Clinical evidence is pending but preliminary results in four melanoma patients showed only limited persistence of GD2-targeted CAR T cells expanded using IL-7 and -15 [31]. Selection of more primitive starting $\mathrm{T}$-cell populations prior to in vitro expansion [14] and use of signaling inhibitors that prevent effector differentiation [32] are other strategies for increasing the number of less-differentiated $\mathrm{T}$ cells for adoptive $\mathrm{T}$-cell therapy.

Increasingly sophisticated cell manufacturing methods have been developed to achieve product reproducibility and high efficiency. Multistep manufacturing procedures may be more vulnerable and could hinder the reproducibility of the manufacturing method, perhaps leading to situations where the patient will not receive the needed cell therapy product. Each manufacturing step and production material included in the method increases substantially the labor needed to fulfill the Good Manufacturing Practice (GMP) requirements because all the raw materials used need to be controlled as well. This ultimately affects the overall production costs and the cost-effectiveness of the treatment.

In this work we investigated if $\mathrm{T}$ cells with preferred early memory phenotypes could be expanded without cytokine supplementation and extra manipulation. We have dissected the relative contributions of simple in vitro cell expansion conditions (IL-2 concentration, the length of expansion) to the cell composition of T-cell product and therapeutic potency. We pose that an optimal cancer-targeting T-cell product encompasses appropriate subpopulation heterogeneity, providing (i) rapid killing efficiency (activated $\mathrm{CD} 8^{+}$ effectors), (ii) $\mathrm{CD}^{+} \mathrm{T}$ cells and (iii) a considerable proportion of less-differentiated, early memory $\mathrm{T}$ cells. In vitro functional studies were performed to assess the functional significance of these results in the context of adoptive T-cell therapy. In this study we have developed an effective and lean T-cell expansion protocol that can be applied to the production of clinically potent CAR T cells. 


\section{Materials and methods}

\section{T-cell expansion}

Peripheral blood mononuclear cells (PBMC) from 10 healthy blood donors were isolated from buffy coats and from two leukemia patients from fresh whole blood samples by density gradient centrifugation using Ficoll-Paque Premium (GE Healthcare). Informed consent was obtained and the study and the use of human material were approved by the institutional review boards at the Finnish Red Cross Blood Service and the Hospital district of Helsinki and Uusimaa. Either fresh or cryopreserved cells were magnetically enriched for $\mathrm{T}$ cells and activated using Dynabeads Human T-Expander CD3/CD28 (Life Technologies) at a 3:1 bead to cell ratio. Cell expansion was conducted in small-scale cultures in $\mathrm{X}$-VIVO 15 (Lonza) with 5\% human $\mathrm{AB}$ serum (Gemini or Seralab) starting with a cell density of $1 \times 10^{6} / \mathrm{mL}$. Expansions from individual donors were cultured in parallel under five different IL-2 (Proleukin, Novartis) concentrations (0, 5, 20, 100 and $300 \mathrm{IU} /$ $\mathrm{mL})$. From the third day onward, the cell density was adjusted to $0.5 \times 10^{6} / \mathrm{mL}$ with IL-2-supplemented culture media every $2-3$ days.

\section{Flow cytometry}

Prior to phenotyping, the cells were fixed with paraformaldehyde. The following antibodies from BD Biosciences were used for staining: anti-CD3fluorescein isothiocyanate (FITC), R-phycoerythrin (PE), BV510 (clone UCHT1) or FITC from Miltenyi Biotec (clone BW264/56), CD4-peridinin chlorophyll protein-cyanin 5.5 (PerCP-Cy5.5) or BV510 (clone SK3), CD8-AlexaFluor647 or BV421 (clone RPA-T8), $\gamma \delta$ TCR-PE (clone 11F2), CD56allophycocyanin (APC, clone B159), CCR7-PE (clone 150503), CD27-PerCP-Cy5.5 (clone M-T271), CD45RA-APC (clone HI100), CD45RO-BV421 (clone UCHL1) and CD95-PE (clone DX2). B-cell elimination from cell expansions was confirmed with anti-CD19-PE (clone HIB19). Appropriate isotype and fluorescence minus one (FMO) controls were used. Memory T-cell subtypes were identified according to the expression of CD27, CD45RA, CD45RO and CD95 as explained in Table I. Altogether 11 expansions (nine healthy donors, two patients) were phenotyped for memory T-cell status. Six of the expansions were transduced with CAR, three with green fluorescent protein (GFP) and two were T-cell expansions without transduction.

All flow cytometric analyses were performed using BD FACSAria IIu (BD Biosciences) and FlowJo (version 7.6 .5 or 10 , TreeStar) software.
Table I. Expression patterns used for T-cell subtype phenotyping.

\begin{tabular}{ll}
\hline Subtype & \\
\hline Naïve & $\mathrm{CD} 95^{-} \mathrm{CD} 45 \mathrm{RO}^{-} \mathrm{CD} 45 \mathrm{RA}^{+} \mathrm{CD} 27^{+}$ \\
$\mathrm{T}_{\mathrm{SCM}}$ & $\mathrm{CD} 95^{+} \mathrm{CD} 45 \mathrm{RO}^{-} \mathrm{CD} 45 \mathrm{RA}^{+} \mathrm{CD} 27^{+}$ \\
$\mathrm{T}_{\mathrm{SCM} \text {-like }}$ & $\mathrm{CD} 95^{+} \mathrm{CD} 45 \mathrm{RO}^{+} \mathrm{CD} 45 \mathrm{RA}^{+} \mathrm{CD} 27^{+}$ \\
$\mathrm{T}_{\mathrm{CM}}$ & $\mathrm{CD} 95^{+} \mathrm{CD} 45 \mathrm{RO}^{+} \mathrm{CD} 45 \mathrm{RA}^{-} \mathrm{CD} 27^{+}$ \\
$\mathrm{T}_{\mathrm{EM}}$ & $\mathrm{CD} 95^{+} \mathrm{CD} 45 \mathrm{RO}^{+} \mathrm{CD} 45 \mathrm{RA}^{-} \mathrm{CD} 27^{-}$ \\
$\mathrm{T}_{\mathrm{Eff}}$ & $\mathrm{CD} 95^{+} \mathrm{CD} 45 \mathrm{RO}^{+} \mathrm{CD} 45 \mathrm{RA}^{+} \mathrm{CD} 27^{-}$ \\
\hline
\end{tabular}

NOTE. Sequential differences in expression between subtypes are shown by underlining. $T_{\mathrm{SCM}}, \mathrm{T}_{\mathrm{SCM} \text {-like }}$ and $\mathrm{T}_{\mathrm{CM}}$ cells represent lessdifferentiated, early memory $\mathrm{T}$ cells.

$\mathrm{T}_{\mathrm{Eff}}$, effector $\mathrm{T}$ cell.

\section{Construction of lentiviral vectors}

The second-generation (2G) CD19-CAR (CD19$\mathrm{scFv} / \mathrm{CD} 28 / \mathrm{z}$ ) was edited from the third-generation (3G) construct (CD19-scFv/CD28/4-1BB/z [33]) by removing the $4-1 \mathrm{BB}$ sequence. Self-inactivating $3 \mathrm{G}$ lentiviral vectors (LVs) encoding CARs were generated by cloning the transgenes (GenScript) into LVs with human phosphoglycerate kinase promoters [34].

\section{Lentiviral transduction and analysis of CD19-CAR expression}

Two days after the activation, $\mathrm{T}$ cells were transduced with LVs encoding either the 2 G or 3 G CD19CAR construct or GFP (data not shown) using a multiplicity of infection of 10 . CD19-CAR-expressing cells were detected by flow cytometry using an AlexaFluor647-conjugated $\mathrm{F}\left(\mathrm{ab}^{\prime}\right)_{2}$ fragment goat antihuman immunoglobulin ( $\mathrm{Ig}) \mathrm{G}(\mathrm{H}+\mathrm{L}$ ) (Jackson Immunoresearch, Inc.). CAR-positive cells were gated using untransduced or empty LV-transduced cells as controls. The background was eliminated by subtracting the percentage of positive cells in control samples from the percentage of positive cells in CD19-CARtransduced samples. Control cells were cultured with $20 \mathrm{IU} / \mathrm{mL}$ IL-2.

\section{$B$-cell lines}

SupB-15 (CD19+ B-lineage acute lymphoblastic leukemia $[\mathrm{ALL}]$ ) cell line was purchased from ATCC. NALM-6 (CD19 ${ }^{+}$B lineage ALL) was obtained from Dr O. Lohi (University of Tampere, Finland). Cell lines were cultured in RPMI-1640 medium (Life Technologies) supplemented with $10 \%$ fetal bovine serum (Life Technologies), $100 \mathrm{IU} / \mathrm{mL}$ penicillin and $100 \mu \mathrm{g} /$ $\mathrm{mL}$ streptomycin (Life Technologies).

\section{Functional characterization of CAR T cells}

CD19-CART-cell functionality was tested using CD19expressing SupB-15 or NALM-6 B lineage ALL cells. Cell proliferation, degranulation and cytokine secretion assays were performed using cryopreserved and 
thawed cells, and fresh cells were used for cytotoxicity testing.

To measure proliferation in response to target cells, CD19-CAR $\mathrm{T}$ cells were labeled with 5(6)carboxyfluorescein diacetate $\mathrm{N}$-succinimidyl ester (CFSE; Life Technologies), and co-cultured for 4 days with NALM-6 at an effector-target cell ratio (E:T) of 10:1. CFSE dilution as a measure of proliferation was detected using flow cytometry.

Cytometric bead array (CBA) was used to measure the release of IL-2 and interferon (IFN) $\gamma$ during a 1-day 1:1 co-culture of CD19-CAR T and NALM- 6 cells. The cytokine concentrations were measured from the culture media using the BD CBA Human Soluble Protein Master Buffer Kit, CBA IL-2 Flex Set and CBA IFN-G Flex Set (BD Biosciences). Results were analyzed using FCAP Array Software Version 3.0 (BD Biosciences).

To measure degranulation in response to target cells, $\mathrm{T}$ cells were incubated at 1:1 with NALM-6 targets for $4 \mathrm{~h}$ in the presence of a CD107a antibody (BD Biosciences, clone H4A3). Degranulating $\mathrm{T}$ cells were identified by the surface expression of the lysosomal-associated protein CD107a using antiCD107a-PE and flow cytometry.

Target cell killing efficacy was evaluated using the calcein release cytotoxicity assay. CD19-expressing SupB-15 or NALM-6 B-ALL target cells were labeled with calcein-acetoxymethyl (Life Technologies) and cocultured at E:T ratios ranging from 0.3:1-30:1. After a 4-h incubation, target cell killing efficiency was determined by measuring the amount of fluorescent calcein released into the culture media using a FLUOstar Omega microplate reader (BMG Labtech).

\section{Statistics}

The differences between expansion conditions were analyzed with Mann-Whitney test and unpaired $t$ test with two-sided $P$ values. In analysis of CBA results, means of multiple groups were compared using oneway analysis of variance (ANOVA) and Tukey multiple comparisons test. Differences were considered statistically significant when $P<0.05$. Analyses were performed using GraphPad Prism (version 6.07) software. The dependence of cell lysis percentage on cell ratios and IL-2 levels was modelled with a linear model using R (version 3.3.1 [35]; see Supplementary file for further details).

\section{Results}

T-cell expansion in low IL-2 concentration bolsters early memory $T$ cells instead of effector phenotypes

IL-2 is a powerful cytokine inducing both clonal T-cell expansion and effector differentiation. We asked if the amount of exogenous IL-2 could be optimized for expansion of therapeutic T-cell preparations. $T$ cells from peripheral blood of nine healthy donors and two patients with leukemia were activated using microbeads carrying CD3 and CD28 antibodies (Dynabeads) and cultured with varying concentrations of exogenously added IL-2 ranging from $0-300 \mathrm{IU} / \mathrm{mL}$. T cells in most expansions were transduced to express either CAR $(n=6)$ or GFP $(n=3)$. On the tenth day of expansion, memory T-cell status was analyzed (Figure 1A). First, we analyzed the proportions of early $T_{M}$ cells, corresponding to $\mathrm{T}_{\mathrm{SCM}}, \mathrm{T}_{\mathrm{SCM} \text {-like }}$ and $\mathrm{T}_{\mathrm{CM}}$ cells. Cultures without or with only $5 \mathrm{IU} / \mathrm{mL}$ IL-2 had an $88 \%-89 \%$ mean proportion of early $\mathrm{T}_{M}$ (Figure $1 \mathrm{~B}$ ). When higher IL-2 concentrations were used for T-cell expansion, the proportion of early $\mathrm{T}_{M}$ decreased, reaching $61 \%$ when using $300 \mathrm{IU} / \mathrm{mL}$ IL-2. The transduction process did not influence the memory T-cell composition as parallel untransduced control expansions gave similar results (data not shown). Thus, the increment of IL-2 decreased the proportion of early memory $\mathrm{T}$ cells.

Each $T$ memory cell subtype, including $\mathrm{T}_{\mathrm{SCM}}, \mathrm{T}_{\mathrm{SCM} \text {-ike, }}$ $\mathrm{T}_{\mathrm{CM}}$ and $\mathrm{T}_{\mathrm{EM}}$ cells, as well as effector $\mathrm{T}$ cell $\left(\mathrm{T}_{\mathrm{Eff}}\right)$, was present in the expanded products on day 10 , whereas naïve $\mathrm{T}$ cells $\left(\mathrm{CD} 95^{-}\right)$were absent after expansion. Increasing the amount of exogenously added IL-2 had its most profound effects on two particular memory T-cell subtypes: it decreased $\mathrm{T}_{\mathrm{CM}}$ and increased $\mathrm{T}_{\mathrm{Eff}}$ levels (Figure 2). $\mathrm{T}_{\mathrm{CM}}$ decreased from the mean level of $32 \%$ accomplished without any exogenous IL-2 to around $10 \%$ when using $20 \mathrm{IU} / \mathrm{mL}$ or more. Conversely, very few $\mathrm{T}_{\text {Eff }}$ were detected in cultures with the two lowest IL-2 conditions ( 0 and $5 \mathrm{IU} / \mathrm{mL}$ ), but their mean proportion increased with increasing exogenous IL-2, reaching $27 \%$ at the highest concentrations. The proportion of the most abundant $T$-cell subtype, the $\mathrm{T}_{\mathrm{SCM} \text {-ike }}$ population comprising roughly half of the cells, was not substantially influenced by the amount of IL-2 supplementation. Also, $100 \mathrm{IU} / \mathrm{mL}$ IL-2, considered here as the current standard often used in T-cell production [36], generated on average a 2.5 -fold smaller proportion of $\mathrm{T}_{\mathrm{CM}}$ and 5.5-fold more $\mathrm{T}_{\mathrm{Eff}}$ compared with $\mathrm{T}$ cells expanded without supplemental IL-2 $(P=0.04$ and $P=0.01$, respectively; Figure 2).

In conclusion, these results demonstrate that an essential shift toward early memory $\mathrm{T}$ phenotypes can be achieved by simply reducing the amount of IL-2 during in vitro T-cell expansion.

\section{Instability of the $T_{S C M}$ population during T-cell expansion}

Cell products from altogether 11 donors (healthy $n=9$; patients $n=2$ ) were phenotyped for their T-memory status on day 10 of the expansion and, surprisingly, six expansions $(55 \%)$ were completely deficient in $\mathrm{T}_{\mathrm{SCM}}$ (Figure 2). Absence of $\mathrm{T}_{\mathrm{SCM}}$ was not IL-2 
A

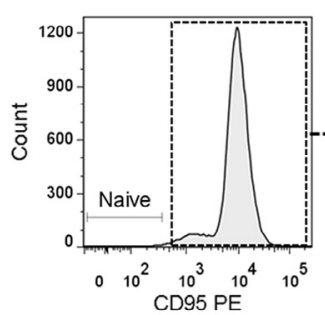

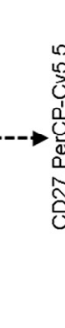
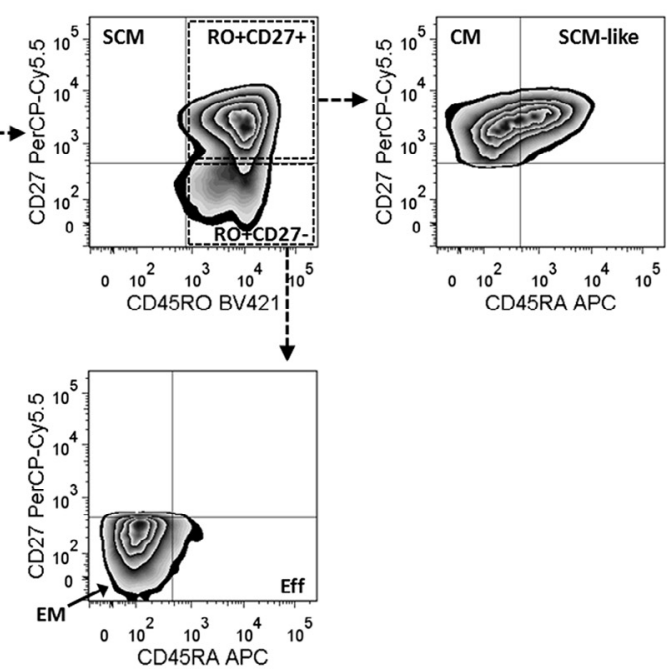

B

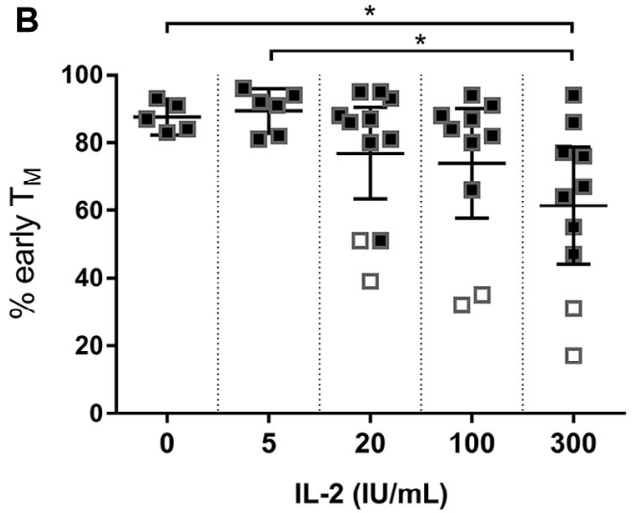

Figure 1. (A) A representative analysis of T memory phenotyping. T cells were expanded for 10 days under 0 IU/mL IL-2. The T-cell subset composition was $0 \%$ naïve, $0 \% \mathrm{~T}_{\mathrm{SCM}}, 37 \% \mathrm{~T}_{\mathrm{SCM} \text {-like, }}, 47 \% \mathrm{~T}_{\mathrm{CM}}, 15 \% \mathrm{~T}_{\mathrm{EM}}$ and $1 \% \mathrm{~T}_{\mathrm{Eff}}$. FMO controls were used for setting the gates. (B) Low IL-2 concentration induces the generation of less-differentiated memory $\mathrm{T}$ cells. $\mathrm{T}$ cells from peripheral blood were activated and expanded in vitro using CD3/CD28 microbeads with IL-2 concentrations ranging from 0-300 IU/mL. The percentages of early memory $\mathrm{T}$ cells, defined as the sum of $\mathrm{T}_{\mathrm{SCM}}, \mathrm{T}_{\mathrm{SCM} \text {-like }}$ and $\mathrm{T}_{\mathrm{CM}}$ cells, were analyzed on the tenth day of the expansion. Cells from five donors were expanded in all the different conditions in parallel. Additional parallel expansions were done for 5-300 IU $/ \mathrm{mL} \mathrm{IL-2} \mathrm{(0} \mathrm{IU} / \mathrm{mL} \mathrm{n}=5$, $5 \mathrm{IU} /$ $\mathrm{mL} n=6,20 \mathrm{IU} / \mathrm{mL} \mathrm{n}=11,100$ and $300 \mathrm{IU} / \mathrm{mL} \mathrm{n}=10$ ). Six expansions were lentivirally transduced with CAR and three with GFP. In two expansions, the cells were not genetically modified. Results from individual expansions are shown along with means and $95 \%$ confidence intervals. Transparent data points represent patient samples and solid data points healthy donor samples. The Mann-Whitney test was used to calculate statistical significance $\left({ }^{\star} P<0.05\right)$.
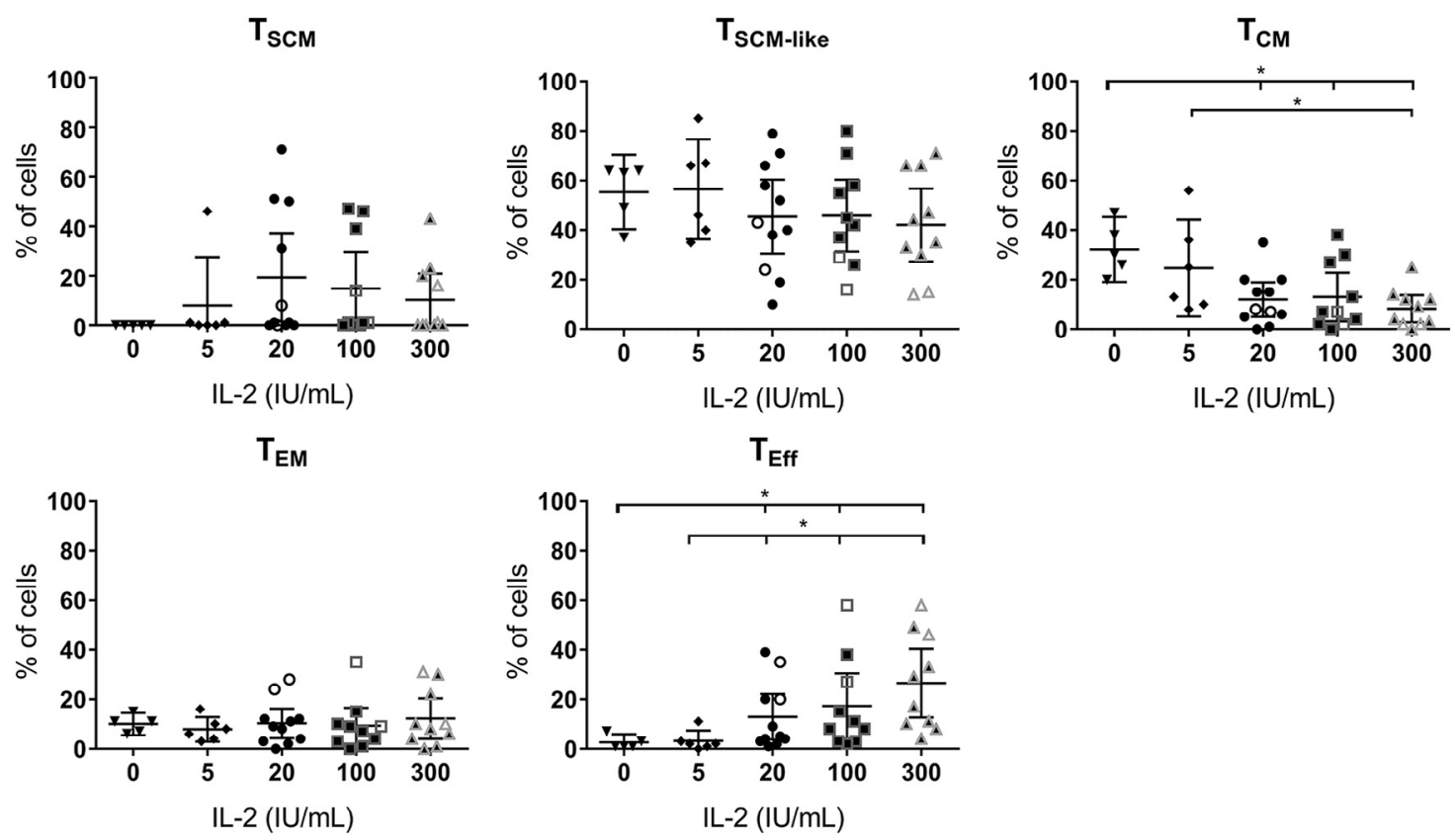

Figure 2. Effect of IL-2 supplementation on memory T-cell subsets in the expanded T-cell products. The proportions of each T-cell subset on the tenth day of in vitro expansion were plotted separately against the corresponding IL- 2 conditions $(0 \mathrm{IU} / \mathrm{mL} \mathrm{n}=5,5 \mathrm{IU} / \mathrm{mL} \mathrm{n}=6$, $20 \mathrm{IU} / \mathrm{mL} \mathrm{n}=11,100$ and $300 \mathrm{IU} / \mathrm{mL} \mathrm{n}=10$ ). Results are shown along with means and $95 \%$ confidence intervals. Transparent data points represent patient samples and solid data points healthy donor samples. The Mann-Whitney test was used to calculate statistical significance $\left({ }^{\star} P<0.05\right)$. 

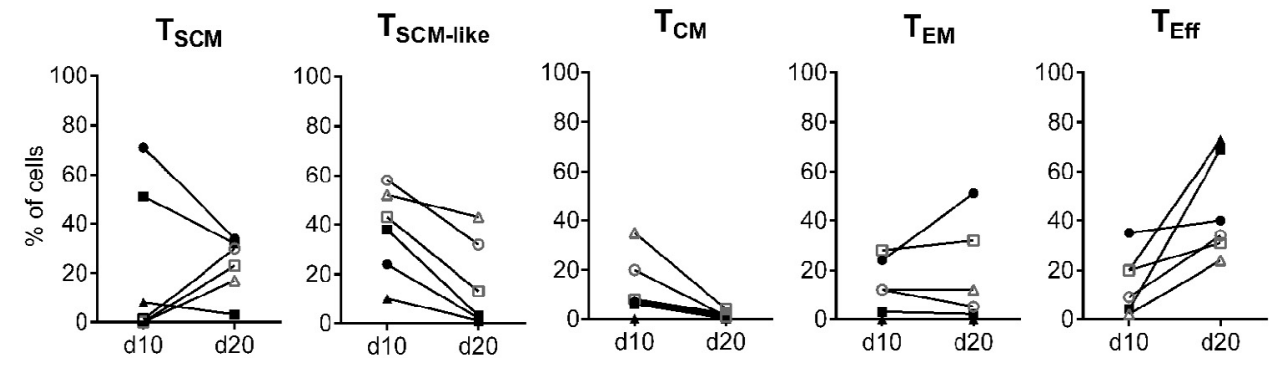

Figure 3. Change in memory T-cell subsets during in vitro T-cell expansion. Cells were phenotyped for their memory status on the tenth and twentieth days of the expansion ( $n=6$; two CAR-transduced, two GFP-transduced and two untransduced). Lines connect results from individual expansions, which are shown with the same symbols in every diagram. The transparent symbols in each plot represent expansions that were negative for $\mathrm{T}_{\mathrm{SCM}}$ on day $10(\mathrm{n}=3)$. Representative data from expansions with $20 \mathrm{IU} / \mathrm{mL}$ IL-2 is shown.

dependent, since expansions deficient for $\mathrm{T}_{\mathrm{SCM}}$ lacked them under all IL-2 conditions (data not shown). Unfortunately, expansions that were also conducted without exogenous IL-2 were, by chance, entirely deficient for $\mathrm{T}_{\mathrm{SCM}}$. The proportion of other early T-memory subtypes, i.e., $\mathrm{T}_{\mathrm{SCM} \text {-like }}$ and $\mathrm{T}_{\mathrm{CM}}$ cells, compensated for the loss of $\mathrm{T}_{\mathrm{SCM}}$. Hence, the total proportion of early memory $\mathrm{T}$ cells was not significantly lower in cultures where no $\mathrm{T}_{\mathrm{SCM}}$ were present.

Six expansions, three containing and three deficient for $\mathrm{T}_{\mathrm{SCM}}$ at day 10 , were cultured further and analyzed again at day 20 (Figure 3). The three expansions that did not have detectable $\mathrm{T}_{\mathrm{SCM}}$ cells on day 10 now had $\mathrm{T}_{\mathrm{SCM}}$ cells at a mean level of $23 \%$ (using $20 \mathrm{IU} / \mathrm{mL}$ IL-2). In contrast, the mean $\mathrm{T}_{\mathrm{SCM}}$ proportion decreased from $43 \%$ to $23 \%$ by day 20 in those expansions that were already positive at day 10 . Contrasting with the instability of the $\mathrm{T}_{\mathrm{SCM}}$ population, a longer expansion time led to a consistent decrease in $\mathrm{T}_{\mathrm{SCM}-\text {-ike }}$ and $\mathrm{T}_{\mathrm{CM}}$, and an increase in the $\mathrm{T}_{\text {Eff }}$ populations (Figure 3 ). The size of the $\mathrm{T}_{\mathrm{EM}}$ subset predominantly remained unchanged.

The reason for this variation in the $\mathrm{T}_{\mathrm{SCM}}$ subset could not be identified but several method-related issues were excluded (e.g., serum batch, culture format [well vs flask], use of fresh vs cryopreserved cells as starting material, laboratory deviations, and type of genetic modification). However, a lower cumulative fold expansion by day 10 was often related to the absence of the $\mathrm{T}_{\mathrm{SCM}}$ subset at this time point. These findings suggest that the presence of $\mathrm{T}_{\mathrm{SCM}}$ cells may be linked to expansion kinetics. These data emphasize the sensitivity of primary cell culturing and elucidates the challenges in cell manufacturing.

In summary, the $\mathrm{T}_{\mathrm{SCM}}$ population was not detected in every expansion product at day 10. However, T-cell cultures that first lacked these cells could bear a prominent population during subsequent expansion.

\section{$A$ shorter in vitro expansion time yields a higher proportion of early memory $T$ cells}

Because we found that the proportion of $\mathrm{T}_{\mathrm{SCM}}$ could change upon prolonged expansion, we next investigated the effect of a longer expansion time on the yield of cells with the desired early memory T-cell phenotype. Using IL-2 concentrations ranging from 0-300 IU/mL, an average 11- to 62-fold expansion of the T-cell product was achieved during the 10-day culture (Table II), and by day 20 of expansion the cells reached 140- to 12 000-fold using 20-300 IU/mL IL-2 (Figure 4). Day 20 data is only available for cultures where 20-300 IU/mL IL-2 was used, because the cells cultured with less cytokine did not proliferate well enough for testing.

Compared with 10 day-long cultures, the day 20 expansion cultures yielded an approximately two-

Table II. Summary of key determinants for 10 day in vitro T-cell expansion under different IL-2 conditions.

\begin{tabular}{lccccc}
\hline & $\begin{array}{c}\text { Early } \mathrm{T}_{M}(\%) ; \text { mean } \\
(\mathrm{min}-\mathrm{max})\end{array}$ & $\begin{array}{c}\text { Cumulative fold expansion; } \\
\text { mean (min-max) }\end{array}$ & $\begin{array}{c}\text { Total yield for early } \\
\mathrm{T}_{M} \text {; mean (min-max) }\end{array}$ & $\begin{array}{c}\mathrm{CD}^{+}(\%) ; \text { mean } \\
\text { (min-max) }\end{array}$ & $\begin{array}{c}\text { Effector } \\
\text { function }\end{array}$ \\
\hline No IL-2 & $88(83-93)$ & $11(4-18)$ & $9.6(3.0-15)$ & $63(43-87)$ \\
$5 \mathrm{IU} / \mathrm{mL}$ IL-2 & $89(81-96)$ & $12(3-21)$ & $11(2.4-19)$ & $58(26-88)$ & + \\
$20 \mathrm{IU} / \mathrm{mL}$ IL-2 & $77(39-95)$ & $39(4-100)$ & $27(3.3-52)$ & $43(12-82)$ & ++ \\
$100 \mathrm{IU} / \mathrm{mL}$ IL-2 & $74(32-94)$ & $60(3-150)$ & $37(2.1-97)$ & $61(19-93)$ & +++ \\
$300 \mathrm{IU} / \mathrm{mL}$ IL-2 & $61(17-94)$ & $62(4-140)$ & $31(2.7-81)$ & $67(26-94)$ & +++ \\
\hline
\end{tabular}

NOTE. $\mathrm{n}=5-12$ depending on condition. The total yield for early memory $\mathrm{T}$ cells was calculated by multiplying the percentage of early $\mathrm{T}_{M}$ with the corresponding cumulative fold expansion. 

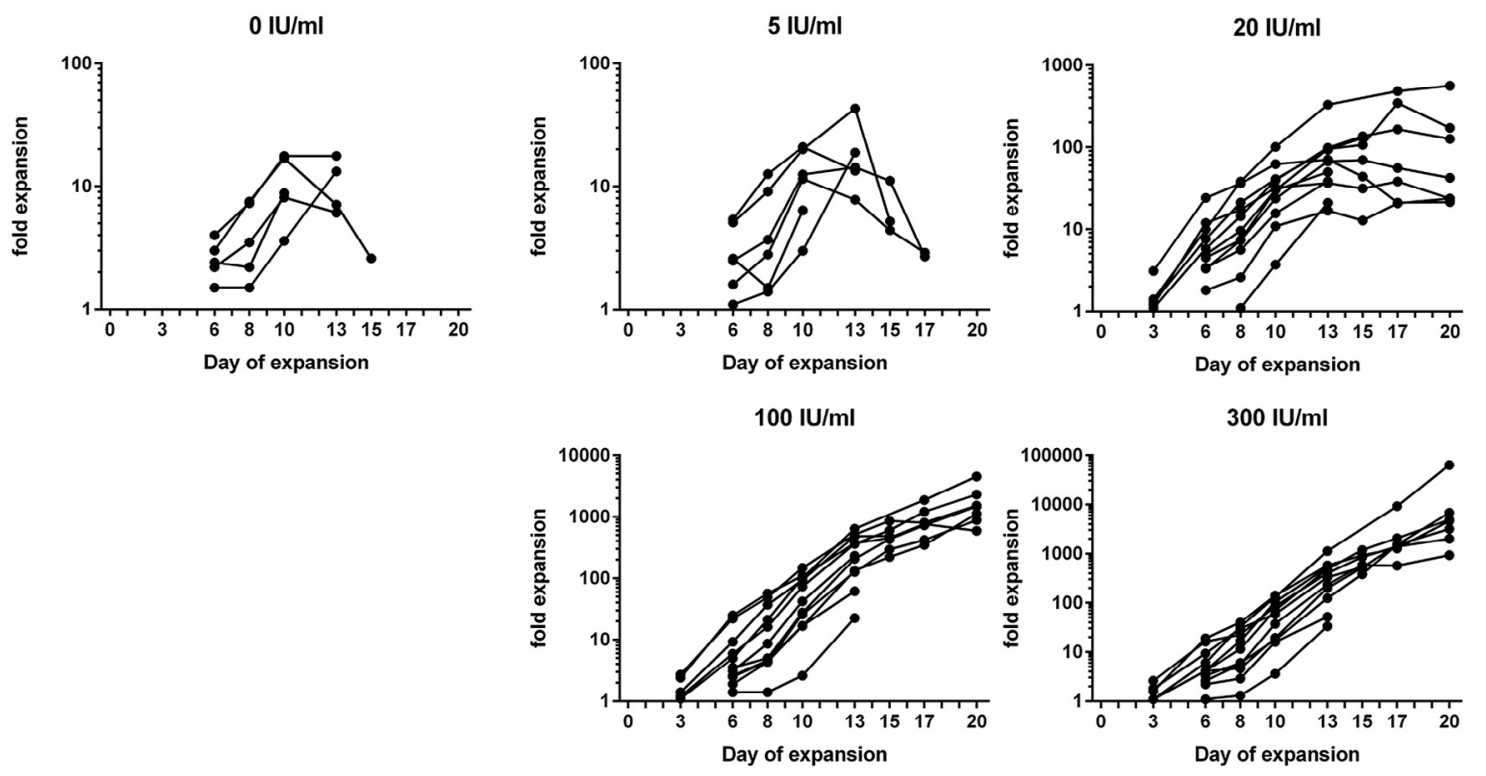

Figure 4. Expansion kinetics for $\mathrm{T}$ cells cultured under different IL-2 conditions $(0 \mathrm{IU} / \mathrm{mL} \mathrm{n}=5,5 \mathrm{IU} / \mathrm{mL} \mathrm{n}=6,20 \mathrm{IU} / \mathrm{mL} \mathrm{n}=12,100$ and $300 \mathrm{IU} / \mathrm{mL} \mathrm{n}=10$ ). Individual expansions are shown on logarithmic scales. Cell expansion was conducted using CD3/CD28 microbeads. The number of viable cells was determined with a hemacytometer and trypan blue exclusion on every other or third day.

fold lower mean level of early memory $\mathrm{T}$ cells with each tested IL-2 concentration $(20-300 \mathrm{IU} / \mathrm{mL}$; Figure 5). Closer subtype analysis in this larger data set confirmed the observations in Figure 3: longer expansion led to a decrease in both $\mathrm{T}_{\mathrm{SCM} \text {-ike }}$ and $\mathrm{T}_{\mathrm{CM}}$ proportions and increased $\mathrm{T}_{\mathrm{Eff}}$ in all three IL-2 conditions (Supplementary Figure $\mathrm{S} 1$ ). Of note, the $\mathrm{T}_{\mathrm{CM}}$ population was practically lost from expansion cultures by day 20 .

These results indicate that, although the total yield of cells is less, shorter in vitro culture may be desirable for clinical T-cell production because it generates $\mathrm{T}$ cells with an early memory status.

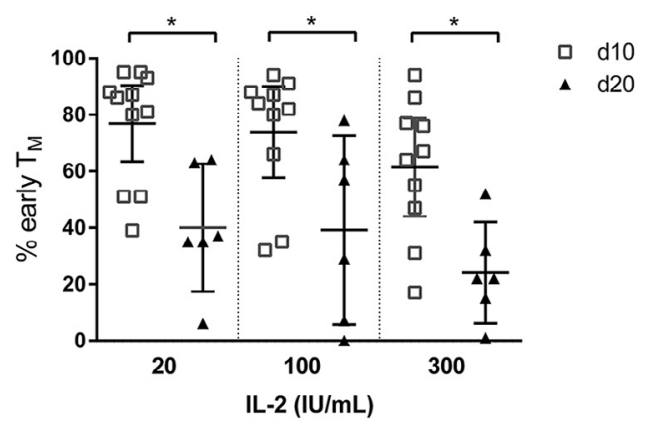

Figure 5. Shorter in vitro culture generates $\mathrm{T}$ cells with an early memory phenotype. The percentages of early memory $T$ cells $\left(T_{\mathrm{SCM}}\right.$, $\mathrm{T}_{\mathrm{SCM} \text {-like }}$ and $\mathrm{T}_{\mathrm{CM}}$ cells) were analyzed on the tenth (transparent symbols, $n=10-11$ ) and twentieth (black symbols, $n=6$ ) day of the expansions using 20-300 IU/mL IL-2. Results from individual expansions are shown along with means and $95 \%$ confidence intervals. Statistical significance was calculated using the MannWhitney test $\left({ }^{\star} P<0.05\right)$.

\section{High IL-2 concentration favors $C D 4^{+} T$ cells but longer expansion time promotes preponderance of $\mathrm{CD} 8^{+}$cells}

The expanded cell products consisted solely of CD3 $\mathrm{T}$ cells ( $>98 \%$ on day 10$)$. No $\gamma \delta \mathrm{T}$ cells were detected, and both $\mathrm{CD} 4^{+}$and $\mathrm{CD} 8^{+}$cells were present in all cultures under all conditions. The proportion of $\mathrm{CD}^{+}$cells at day 10 varied considerably between expansions (e.g., proportion of $\mathrm{CD} 4^{+}$cells ranged from $12 \%-82 \%$ with $20 \mathrm{IU} / \mathrm{mL}$ IL-2; Figure 6 and Table II). A high concentration of IL-2 led to a somewhat higher

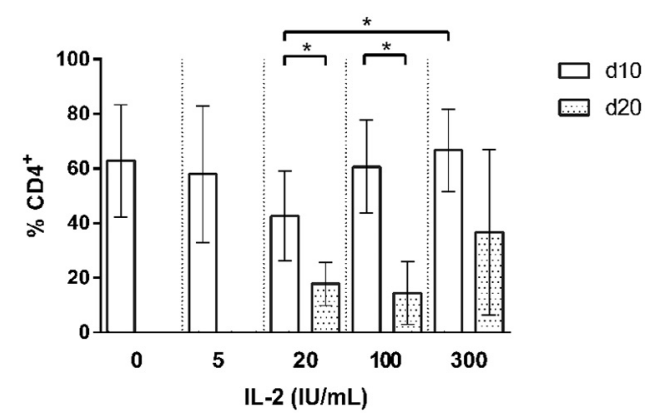

Figure 6. Effect of IL-2 supplementation and expansion time on the number of $\mathrm{CD} 4^{+}$cells. T cells expanded under different IL-2 conditions were analyzed for their $\mathrm{CD} 4^{+} \mathrm{T}$-cell content at two time points (day 10, transparent bars, and 20, solid bars). Data are from five to 11 independent expansions depending on the time point and experimental condition. Data for day 20 is only available for 20 $300 \mathrm{IU} / \mathrm{mL}$ IL-2 because the cells did not proliferate well enough for testing when less IL-2 was added. Means with 95\% confidence intervals are shown, and the Mann-Whitney test was used to calculate statistical significance $\left({ }^{\star} P<0.05\right)$. 
fraction of $\mathrm{CD}^{+}$. In contrast, longer expansion times favored $\mathrm{CD}^{+}$over $\mathrm{CD} 4^{+}$cells (Figure 6 ). Under all tested IL-2 conditions $(20-300 \mathrm{IU} / \mathrm{mL})$ there was a 2- to 4 -fold decrease in $\mathrm{CD}^{+}$and a reciprocal increase in $\mathrm{CD}^{+}$proportions from day 10 to day 20. Thus, expansion time had major effect on T-cell populations by altering the cell balance toward $\mathrm{CD} 8^{+} \mathrm{T}$-cell dominance.

A small fraction of the expanded $\mathrm{T}$ cells gained CD56 expression by day 20 of expansion (data not shown). These cytokine induced killer (CIK)-type cells comprised approximately $10 \%$ of the cell product, regardless of the IL-2 concentration used (20-300 IU/ $\mathrm{mL}$ ). Similar data have been reported by others but already after 10 days of expansion [36].

In summary, the relative proportions of $\mathrm{CD} 4^{+}$and $\mathrm{CD}^{+} \mathrm{T}$ cells in in vitro $\mathrm{T}$-cell expansion are affected by both the level of exogenous IL-2 and length of expansion. $\mathrm{CD}^{+}$-enriched products can be generated using a high concentration of IL-2 ( $\geq 100 \mathrm{IU} / \mathrm{mL})$ for about 1 week. On the other hand, a longer expansion protocol yields products consisting predominantly of $\mathrm{CD}^{+}$cells.

\section{IL-2 concentration affects particularly the memory T-cell subtype distribution of $\mathrm{CD}^{+}$cells}

We also asked if memory status was differently affected among expanded $\mathrm{CD} 8^{+}$and $\mathrm{CD} 4^{+} \mathrm{T}$ cells. In both populations the mean proportion of early memory $\mathrm{T}$ cells was high on day 10 under different IL-2 conditions, being $73 \%-91 \%$ for $\mathrm{CD}^{+}$(Supplementary Figure S2A) and $66 \%-88 \%$ for $\mathrm{CD}^{+}$cells (Supplementary Figure S2B). Use of high IL-2 concentration during expansion led to a decrease in early memory $\mathrm{T}$ cells in both populations as already demonstrated for total $\mathrm{T}$ cells (Figure 1B) but the differences reached statistical significance only in the $\mathrm{CD} 4^{+}$population. IL-2 induced $\mathrm{T}_{\mathrm{Eff}}$ differentiation in both $\mathrm{CD}^{+}$and $\mathrm{CD}^{+} \mathrm{T}$ cells and lower levels of IL-2 yielded higher $\mathrm{T}_{\mathrm{CM}}$ numbers at day 10 (Supplementary Figure S3).

If the culture time was extended up to 20 days, only $20 \%-40 \%$ of cells represented early $\mathrm{T}_{M}$ subtypes in both $\mathrm{CD} 8^{+}$and $\mathrm{CD} 4^{+}$cells when $20-300 \mathrm{IU} /$ mL IL-2 was used, and $60 \%-80 \%$ of the cells consisted of $\mathrm{T}_{\mathrm{EM}}$ and $\mathrm{T}_{\mathrm{Eff}}$ cells $(\mathrm{n}=5$, data not shown). At 20 days, increasing IL-2 concentration had a similar effect to what was was seen already on day 10: high concentration of IL-2 (300 IU/mL) favored the generation of higher proportions of $\mathrm{T}_{\mathrm{Eff}}(66 \%$ and $64 \%$, respectively) within the $\mathrm{CD}^{+}$and $\mathrm{CD} 4^{+}$fractions, whereas less $\mathrm{T}_{\mathrm{Eff}}(50 \%$ and $38 \%$, respectively) were generated using $20 \mathrm{IU} / \mathrm{mL}$ IL-2. Conversely, high IL-2 concentration led to reduced generation of early $T_{M}$ cells.

In summary, exogenous IL-2 increment in the in vitro $\mathrm{T}$-cell expansion affects particularly $\mathrm{CD} 4^{+} \mathrm{T}$-cell memory distribution leading to less early memory $\mathrm{T}$ cells and a preponderance of differentiated effector cells.

\section{CD19-CAR T cells expanded under different IL-2 conditions had versatile in vitro effector functions and were target-specific}

CD19-CAR expression was analyzed at day 10 of T-cell expansion (8 days post-transduction) using flow cytometry (Figure 7A and 7B). The mean percentage of CAR-expressing cells was $52 \%$ (range, $8 \%-$ $89 \%$ ), and the level of IL-2 supplementation had no apparent effect on transduction efficiency. Both $2 \mathrm{G}$ and $3 \mathrm{G}$ CAR constructs were successfully expressed on primary human $\mathrm{T}$ cells.

Several assays were performed to analyze the impact of varying IL-2 supplementation on the functional characteristics of the CD19-targeted CAR T cells (Figure 7). Buffy coats from three donors (donors 1-3) were used to generate CAR T cells using the five different IL-2 concentrations $(0-300 \mathrm{IU} / \mathrm{mL})$, and the resulting cells were then subjected to proliferation,

\footnotetext{
Figure 7. Lentivirally transduced T cells express CD19-CAR and demonstrate in vitro activity against B-ALL. Human primary T cells were transduced with lentiviral vectors carrying $2 \mathrm{G}$ or $3 \mathrm{G}$ CD19-CAR-transgenes and expanded under IL-2 concentrations ranging from 0-300 IU/mL IL-2. (A) CAR expression at day 10 of T-cell expansion, mean percentages of CAR-expressing cells with $95 \%$ confidence intervals are shown. The transparent data points represent $2 \mathrm{G}$ and solid data points $3 \mathrm{G}$ CAR $(20 \mathrm{IU} / \mathrm{mL} \mathrm{IL}-2 \mathrm{n}=9$, others $\mathrm{n}=6)$. (B) A representative histogram of CAR expression on 3G CAR-transduced (dark) and untransduced control (transparent) $\mathrm{T}$ cells expanded under $20 \mathrm{IU} / \mathrm{mL}$ IL-2. (C) Proliferation activity of CFSE-labeled CAR-transduced T cells during a 4-day co-culture with CD19+ NALM-6 B-ALL cells shown as percentages of proliferating cells. (D) Degranulation activity of NALM-6-stimulated CAR-transduced T cells shown as percentages of CD107a+ cells. (C-D) Results shown from CAR T cells generated from three donors, each bar representing results obtained with one donor's cells. (E) The secretion of IFN $\gamma$ and IL-2 (pg/mL) measured from co-cultures of CAR-transduced T cells and NALM-6 $(n=3)$. Data from one representative expansion with mean $+S D$ of three replicate measurements are shown. (F) Cytotoxicity of CARtransduced T cells incubated with CD19+ SupB-15 B-ALL targets was measured with the calcein release assay. Mean percentages of target cell lysis in four independent experiments are shown. SDs are omitted for clarity, but ranged from 5\%-35\%. One-way ANOVA with Tukey correction for multiple comparisons was used for analysis of cytokine results (E). In IFN $\gamma$ secretion, $P<0.05$ between all other groups except for 5 vs $20 \mathrm{IU} / \mathrm{mL}$ IL-2 ( $P=$ not significant [NS]), which is shown for clarity. The Mann-Whitney test was used to calculate statistical significances for other assays $\left({ }^{\star} P<0.05\right)$.
} 
A

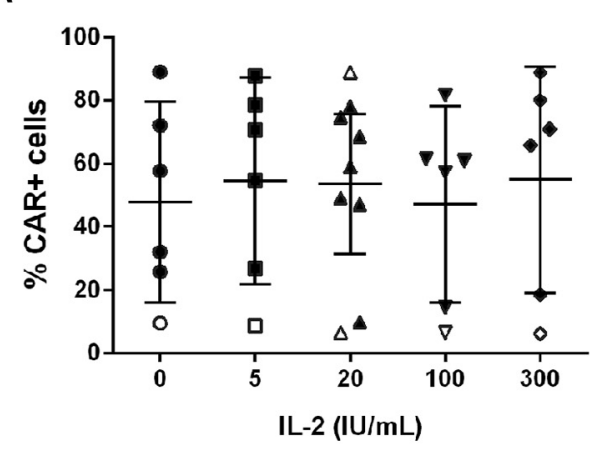

C

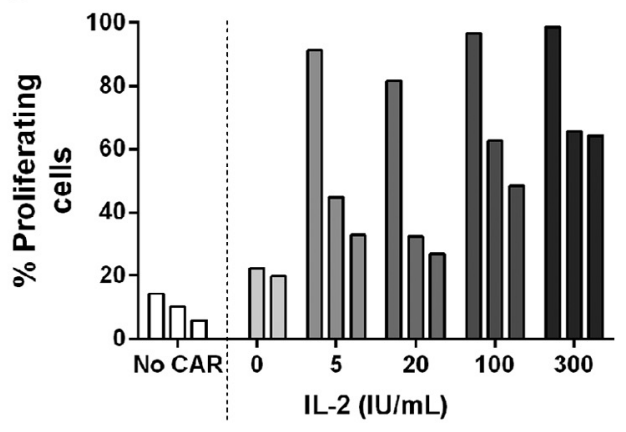

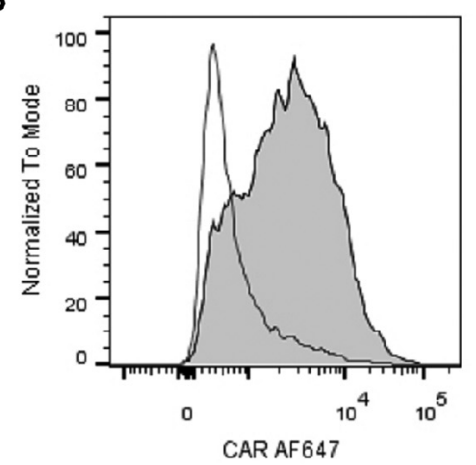

D

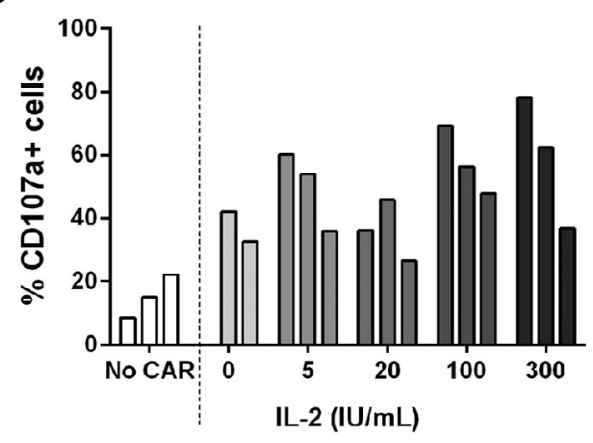

E

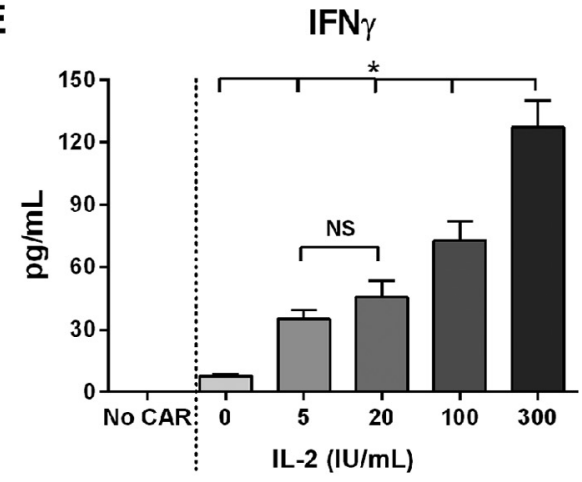

$\mathbf{F}$

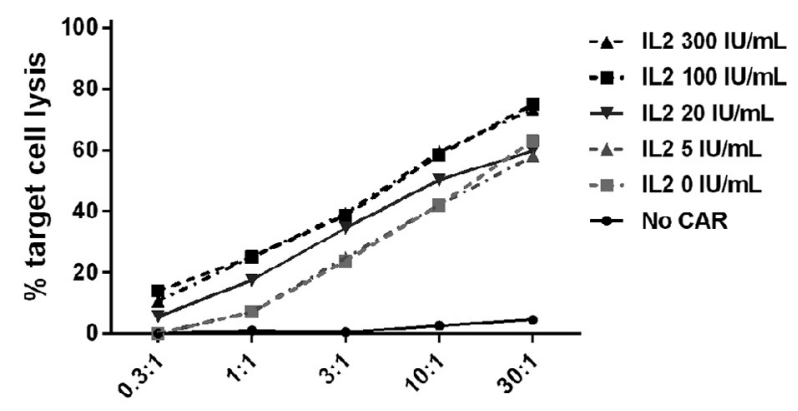

E:T ratio

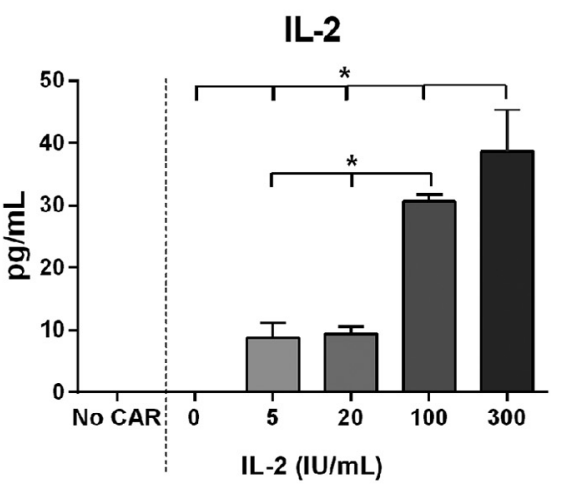

$\mathrm{LL}-2(\mathrm{IU} / \mathrm{mL})$ 
degranulation and cytokine secretion assays. Transduction efficiency varied between the three donors, being $73 \%$ (range, $61 \%-80 \%$ ), $51 \%$ (range, $21 \%$ $66 \%$ ) and $8 \%$ (range, $6 \%-10 \%$ ), respectively. In all of the functionality tests, all CD19-CART cells showed elevated activity compared with untransduced or empty-LV transduced $\mathrm{T}$ cells (Figure 7C-7E), indicating that the observed CAR T-cell functions were dependent on CAR expression. The strength of the anti-B-ALL degranulation, proliferation and cytokine secretion response varied between the three tested CAR T-cell expansions, higher response correlating with the higher proportion of CAR-positive cells (Figure 7C-7E). In all three expansions and regardless of transduction efficiency, the increase of exogenous IL-2 used for CAR T-cell production led to more active degranulation, proliferation and secretion of IL-2 and IFN- $\gamma$ in response to target cells (Figure 7C-7E). These results are in agreement with our finding that higher IL-2 concentrations during T-cell expansion yield higher proportions of more differentiated effector $\mathrm{T}$ cells.

Cytotoxic potency was measured using the calcein release assay. CD19-CAR T-cell products produced under different IL-2 concentrations all demonstrated efficient and dose-dependent killing of SupB15 and NALM- 6 cells (Figure 7F and Supplementary Figure S4). In addition, CD19-CAR T cells showed minimal cytotoxicity against the CD19-negative B-cell line BC-3 (data not shown), and untransduced and empty-LV transduced T cells showed minimal target cell lysis (Figure 7F and Supplementary Figure S4), confirming that the killing was antigen-specific and dependent on CAR expression. Furthermore, expanding the cells in a high concentration of IL-2 (100 and $300 \mathrm{IU} / \mathrm{mL}$ ) enhanced the killing of $\mathrm{CD} 19^{+}$target cells compared with cells grown without IL-2 (Figure 7F; $P<0.0001$ and $P<0.0004$, respectively, by a linear modelling analysis, i.e., analysis of covariance; see supplementary file for details.).

In summary, CD19-CAR T cells demonstrated versatile in vitro functions, and the observed T-cell response against B-ALL cells was antigen-specific and dependent on CD19-CAR expression. Moreover, in vitro antileukemia response of CD19-CART cells was enhanced by the increase of exogenous IL-2 used during T-cell expansion, a change that also favored effector cell differentiation as detected using $T_{M}$ phenotyping.

\section{Dissection for the clinical CD19-CAR T-cell production protocol}

Determining the best expansion conditions for $\mathrm{T}$ cells is complex (Table II). Furthermore, also the lowest values in key determinants, not only the average values, are significant for reproducible and cost-effective manufacturing. The appropriate clinical cell dose for CAR
T cells is not known and may depend on the cell phenotype in the product. With a target of $2 \times 10^{6}$ cells/ $\mathrm{kg}$ patient weight $[4,37]$, we estimate that a 25 -fold cumulative fold expansion in cell number would be needed to cover all patients. On the other hand, only a five-fold T-cell expansion has been used as a highly predictive threshold for successful clinical CAR T-cell manufacturing [28]. Also, high treatment efficacy with low toxicity was achieved with only $0.2 \times 10^{6}$ CD19CAR T cells/ $\mathrm{kg}$ with a defined 1:1 CD4:CD8 ratio [38]. Such cell dosing in our estimations corresponds to a three-fold cell expansion only. The total yield for early memory $\mathrm{T}$ cells (Table II and Supplementary Figure S5) is pivotal if pure cell populations, and hence also further cell selection, are preferred.

We hypothesize that an effective T-cell product encompasses appropriate subpopulation heterogeneity providing rapid $\mathrm{CD} 8^{+}$effector functions, $\mathrm{CD} 4^{+}$cells and early $\mathrm{T}$ memory cells. T-cell expansion without IL-2 supplementation yielded an average of $88 \%$ early $\mathrm{T}_{M}$ cells at lowest $83 \%$ in 10 days (Table II). The average $\mathrm{T}$-cell subset composition was $0 \% \mathrm{~T}_{\mathrm{SCM}}, 55 \%$ $\mathrm{T}_{\mathrm{SCM}-\mathrm{ike}}, 32 \% \mathrm{~T}_{\mathrm{CM}}, 10 \% \mathrm{~T}_{\mathrm{EM}}$ and $3 \% \mathrm{~T}_{\mathrm{Eff}}$. In comparison, $100 \mathrm{IU} / \mathrm{mL}$ IL-2, the current standard used for $\mathrm{T}$-cell expansion, yielded $15 \% \mathrm{~T}_{\mathrm{SCM}}, 46 \% \mathrm{~T}_{\mathrm{SCM} \text {-like, }} 13 \%$ $\mathrm{T}_{\mathrm{CM}}, 9 \% \mathrm{~T}_{\mathrm{EM}}$ and $17 \% \mathrm{~T}_{\mathrm{Eff}}$. Both $\mathrm{CD}^{+}$and $\mathrm{CD}^{+}$cells were generated, and the cells showed functional potency in vitro. The lowest expansion level without supplemental IL-2 was four-fold but on average 11 -fold, corresponding to cell dosing between $0.2 \times 10^{6} / \mathrm{kg}-$ $1 \times 10^{6} / \mathrm{kg}$. By using $100 \mathrm{IU} / \mathrm{mL}$ IL-2, the mean cell expansion was 60-fold (range, 3-15; Table II), which would provide cell dosing up to $5 \times 10^{6} / \mathrm{kg}$. Doseescalation studies are needed to define the T-cell expansion condition providing the best balance between T-cell subset composition and sufficient total cell number.

\section{Discussion}

IL-2, as "the T-cell growth factor" has been used extensively for expansion of T-cells in vitro. Its use has been challenged in recent years as the role of persistent T-cell memory for the clinical success of cancer treatment has gained focus. Thus, the impetus to control effector cell differentiation and memory formation is high. We show here that significant numbers of less-differentiated memory $\mathrm{T}$ cells can be generated simply by limiting the IL-2 concentration during cell expansion. Use of higher amounts of IL-2 reduced the generation of early $T_{M}$ by decreasing central memory $\mathrm{T}$ cells and simultaneously increasing differentiated effectors.

To our knowledge, systematic analysis of IL-2 supplementation for in vitro CAR T-cell expansion has 
not been reported. Here, we have analyzed the association between IL-2 concentration, expansion kinetics and memory T-cell formation using the $\mathrm{CD} 3 / \mathrm{CD} 28$ microbead protocol for T-cell activation. Our data demonstrate that conditions that predominantly rely on autonomous $\mathrm{IL}-2$ production $(0$ and $5 \mathrm{IU} / \mathrm{mL})$ induced T-cell proliferation for only $\sim 10$ days resembling the expansion kinetics of a normal immune response and by that time yielded the highest proportions of early $\mathrm{T}$ memory cells. Low IL-2 concentration (20 IU/ $\mathrm{mL}$ ) still limited cell proliferation to 2 weeks. Higher IL-2 concentrations, that offered $\mathrm{T}$ cells seemingly an unlimited source of proliferative signals (100 and $300 \mathrm{IU} / \mathrm{mL}$ ), led to the accumulation of effector cells already by the tenth day of expansion. One hundred or $300 \mathrm{IU} / \mathrm{mL} \mathrm{IL-2}$ is commonly used for in vitro T-cell expansion and even higher supplementation is used for TILs $[39,40]$. Thus, it may be that in vitro conditions that override the natural physiological course of memory T-cell formation, e.g., high IL-2 concentration, may not be able to generate a significant memory cell pool.

In addition to the present study, two publications have reported in vitro T-cell expansion without any cytokine supplementation. The first one compared two common CART-cell culturing methods used in early trials: soluble anti-CD3 with $300 \mathrm{IU} / \mathrm{mL}$ IL-2 to $\mathrm{CD} 3 / \mathrm{CD} 28$ microbeads without any exogenous IL-2 [13]. They showed that the bead-based protocol produced a younger T-cell phenotype with greater proliferative capacity and better performance in an in vivo model. Still, it was not clear if the improved results were obtained due to the CD28 cosignal, provision of more physiological activation by bead-bound instead of soluble antibodies or lack of IL-2 supplementation. Our results here indicate that omitting IL-2 was at least partly responsible for the better outcome. The second report investigated the occasional poor in vitro expansion potential of $\mathrm{T}$ cells derived from patients with B-cell malignancies [28]; one-fourth of patients were excluded from a CD19 CAR clinical trial because of unsuccessful T-cell expansion. Furthermore, the presence of naïve or early $\mathrm{T}$ memory cells ( $\mathrm{T}_{\mathrm{SCM}}$ and $\mathrm{T}_{\mathrm{CM}}$ ) correlated with successful expansion. Together with our results, these studies demonstrate that in vitro T-cell expansion without any cytokine supplementation provides persistence-related early $\mathrm{T}_{M}$ cells with increased in vivo anti-tumor efficacy both in the pre-clinical and clinical setting and provides a feasible method for most patients with B-cell malignancies.

T-cell expansion without IL-2 naturally affected the final cell numbers. In our material mainly from healthy donors (two leukemia patients were included), we were able to improve the cell yield without markedly compromising the proportion of less-differentiated memory cells by slightly elevating the IL-2 to $20 \mathrm{IU} / \mathrm{mL}$. This improved the mean cell numbers four-fold by day 10 of the expansion. Higher IL-2 concentrations, namely 100 and $300 \mathrm{IU} / \mathrm{mL}$, further increased the mean cell yield by six-fold compared with expansions relying on autonomous IL-2 production only. Yet, the expansion efficiency is likely lower with patient-derived cell material, although such difference was not observed in this study. Efficient expansion in the absence of IL-2 can also be obtained using IL-7 and IL-15, which was needed especially for patients with lymphoma [28].

IL-7 and IL-15 have been explored in in vitro T-cell expansion with a goal to generate early $\mathrm{T}_{M}$. In normal donors early $\mathrm{T}_{\mathrm{M}}$ or $\mathrm{CD} 45 \mathrm{RO}^{+} \mathrm{T}_{\mathrm{SCM}} \mathrm{s}$ (i.e., $\mathrm{T}_{\mathrm{SCM} \text {-like }}$ cells) alone were increased 10\%-30\% compared with expansions relying on a high IL-2 concentration (100$300 \mathrm{IU} / \mathrm{mL})[25,27,30]$. Here we accomplished an increase of similar size $(5 \%-30 \%)$ in early $\mathrm{T}_{M}$ simply by limiting IL-2 supplementation from the current standard. Compared with no cytokine supplementation, IL-7 and IL- 15 induced a $10 \%-20 \%$ gain in the number of $\mathrm{T}_{\mathrm{SCM}}$ in products derived from cancer patients' cells. Singh et al. also revealed a simultaneous IL-7 and IL-15-induced decrease in $\mathrm{T}_{\mathrm{CM}}$ and, interestingly, an increase in $\mathrm{T}_{\mathrm{Eff}}[28] . \mathrm{T}_{\mathrm{SCM}-\text { enriched CAR }}$ T-cell products can also be produced by combining careful cell selection technology with use of homeostatic cytokines and signaling inhibitors [32]. To conclude, our method using a limited amount of IL-2 during T-cell expansion offers a simple, less manipulative and cost-effective alternative for increasing the proportion of less-differentiated memory $\mathrm{T}$ cells.

Among other early $T_{M}$ subsets, we were able to produce $\mathrm{T}$ memory stem cells $\left(\mathrm{CD} 95^{+} \mathrm{CD} 45 \mathrm{RO}^{-} \mathrm{CD} 45 \mathrm{RA}^{+} \mathrm{CD} 27^{+}\right) . \mathrm{T}_{\mathrm{SCM}}$ generation was not IL-2 dependent. Although $\mathrm{T}_{\mathrm{SCM}} \mathrm{S}$ were not present in every expansion at a specific time point, each culture that was analyzed more than once contained these cells either on day 10 or day 20. Furthermore, cultures lacking $\mathrm{T}_{\mathrm{SCM}} \mathrm{S}$ on the tenth day of expansion proliferated poorly during the first week of expansion, possibly linking the presence of $\mathrm{T}_{\mathrm{SCM}} \mathrm{S}$ to expansion kinetics. It is somewhat perplexing how a culture lacking naïve cells and $\mathrm{T}_{\mathrm{SCM}} \mathrm{s}$, the two leastdifferentiated $\mathrm{T}$-cell subsets, can contain $\mathrm{T}_{\mathrm{SCM}} \mathrm{s}$ later during expansion. However, it is possible that these subsets were present but below our detection limit. Also, it is not firmly established if memory T-cell generation follows the progressive differentiation model where less-differentiated subsets function as precursors for more differentiated ones [41].

Most in vitro expansion protocols lack the ability to generate $\mathrm{T}_{\mathrm{SCM}} \mathrm{S}$ but produce so-called $\mathrm{T}_{\mathrm{SCM}}$-like cells that have gained the expression of CD45RO

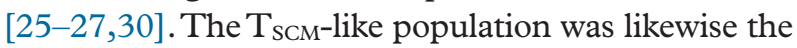
major memory subset present using our expansion protocol. It is not currently known which of the early $\mathrm{T}$ 
memory subsets $\left(\mathrm{T}_{\mathrm{SCM}}, \mathrm{T}_{\mathrm{SCM} \text {-like }}\right.$ or $\left.\mathrm{T}_{\mathrm{CM}}\right)$ provides the best clinical efficacy in humans. A certain level of cell subset heterogeneity can be a good strategy. Thus, lengthening the expansion time to increase the $T_{\mathrm{SCM}}$ proportion is probably not feasible as the proportion of total early memory $\mathrm{T}$ cells decreases. However, finding out the factors inducing the generation of $\mathrm{T}_{\mathrm{SCM}} \mathrm{S}$ in our system would be of substantial scientific interest. Such factors may also have potential in the production of adoptive T-cell products. T-cell-derived natural components may facilitate development of less manipulative ways to produce $\mathrm{T}_{\mathrm{SCM}}$ cells. IL-7 may provide key signals for the formation of $\mathrm{T}_{\mathrm{SCM}}$-like cells together with IL-15 [25] and of $\mathrm{T}_{\mathrm{SCM}}$ cells together with IL-21 and additional modification of intracellular signaling [32]. IL-7 or IL-15 is not produced by T cells themselves, but IL-21 and IL-9 are produced by activated $\mathrm{CD} 4^{+} \mathrm{T}$ cells [24]. IL-9 supports T-cell growth during late phases of immune responses. Interestingly, it also supports anti-tumor activity and survival of TIL through apoptosis resistance [42]. We do not know if the cells in our expansion protocol produced IL-9 or IL-21. However, knowing that early $\mathrm{T}_{M}$ and $\mathrm{CD} 4^{+}$cells correlate with T-cell persistence in a clinical setting [10] and that $\mathrm{CD}^{+}$cells are a prerequisite for mouse memory T-cell formation $[19,20]$, it is tempting to hypothesize that $\mathrm{CD} 4^{+}$ cells might play a role in $\mathrm{T}_{\mathrm{SCM}}$ generation. As growth kinetics played a role, we hypothesize that $\mathrm{T}_{\mathrm{SCM}}$ generation is induced by factors produced by $\mathrm{CD} 4^{+} \mathrm{T}$ cells after their peak proliferation.

The significance of $\mathrm{CD} 4^{+}$cells was recently demonstrated in a sophisticated CAR T-cell study [14]. The authors postulated that IL-2 produced by $\mathrm{CD} 4^{+}$ cells drove the enhanced $\mathrm{CD} 8^{+}$proliferation in vivo that correlated with efficacy. According to their data, $60 \%$ of $\mathrm{CD}^{+}$and $75 \%$ of $\mathrm{CD}^{+}$cells expressed CD45RO and CD27 and thus represented early $T_{M}$. A similar cellular distribution was obtained with our simplified method in a 10-day expansion using IL-2 at $20-100 \mathrm{IU} / \mathrm{mL}$. Due to the prominent role of $\mathrm{CD} 4^{+} \mathrm{T}$ cells in adoptive T-cell therapy, a better understanding of their optimal proportion and how expansion conditions impact their numbers in relation to $\mathrm{CD} 8^{+} \mathrm{T}$ cells is needed. We show that the proportion of $\mathrm{CD}^{+}$cells is increased if very low or high concentrations of supplemental IL-2 are used, but that extending the expansion time from 10 to 20 days leads to the accumulation of $\mathrm{CD}^{+}$cells at the expense of $\mathrm{CD} 4^{+}$.

Several studies indicate that improved in vivo performance in humans $[9,10]$ and animal models $[11-14]$ is achieved with T-cell products that contain early memory $\mathrm{T}$ cells, either $\mathrm{T}_{\mathrm{SCM}}, \mathrm{T}_{\mathrm{SCM} \text {-like }}$ or $\mathrm{T}_{\mathrm{CM}}$. In addition to memory T-cell phenotyping, we showed that the cell products expanded under different IL-2 con- ditions had differences in in vitro function. Although the tests do not measure persistence, the results demonstrate that the products differ functionally. For these reasons, even though these studies did not include in vivo testing, it is reasonable to infer that improved in vivo performance may be achieved using the cells produced with low IL-2 supplementation as well.

One more consideration regarding the use of early memory $T$ cells in the treatment of cancer remains unresolved. Assuming that in vitro-generated early memory $\mathrm{T}$ cells have a similar homing capacity to their physiological counterparts $[12,15]$, they will have limited potential to enter peripheral tissues such as tumors, and rather home to lymphoid organs for activation by antigen-presenting cells. In cancer, the function of antigen-presenting cells is often suppressed. Thus, early memory cell-enriched T-cell products may be particularly effective in hematologic malignancies where malignant target cells are found in lymphoid organs, but less so in solid tumors lacking lymph node metastasis.

Less-differentiated memory $\mathrm{T}$ cells are critical for clinical anti-tumor efficiency. We demonstrate that the number of early $\mathrm{T}_{M}$ cells in a T-cell preparation can be increased by simply reducing the IL-2 amount used during in vitro T-cell expansion. In light of our results, the necessity of sophisticated multi-step protocols may need re-evaluation. These findings are significant for robust and cost-effective clinical T-cell manufacturing.

\section{Acknowledgments}

The authors acknowledge Gianpietro Dotti from the Center for Cell and Gene Therapy, Baylor College of Medicine, Houston, Texas, for providing the CD19directed CAR genes. From the Finnish Red Cross Blood Service we thank Sirkka Hirschovits-Gerz and Kaarina Lähteenmäki for professional assistance and Johanna Nystedt for valuable comments on the manuscript. The study was partially funded by the VTR State Research Funding for Finnish Red Cross Blood Service, the Pediatric Research Foundation and the Noona and Kullervo Väre Foundation. The funding sources did not influence the study design or writing of the manuscript.

Disclosure of interests: Dr Loskog is the CEO of Lokon Pharma, executive chairman of Vivolux, chairman of RePos Pharma, board member of Lokon Pharma, Bioimics and Hansa Medical (Publ) and advisor to Nexttobe and Olink Proteomics. She has royalty agreements with Lokon Pharma and Alligator Bioscience and a contract research agreement with Lokon Pharma. The remaining authors declare no conflict of interest. 


\section{References}

[1] Maus MV, Fraietta JA, Levine BL, Kalos M, Zhao Y, June $\mathrm{CH}$. Adoptive immunotherapy for cancer or viruses. Annu Rev Immunol 2014;32:189-225.

[2] Rosenberg SA, Yang JC, Sherry RM, Kammula US, Hughes MS, Phan GQ, et al. Durable complete responses in heavily pretreated patients with metastatic melanoma using T-cell transfer immunotherapy. Clin Cancer Res 2011;17:4550-7.

[3] Rapoport AP, Stadtmauer EA, Binder-Scholl GK, Goloubeva O, Vogl DT, Lacey SF, et al. NY-ESO-1-specific TCRengineered $\mathrm{T}$ cells mediate sustained antigen-specific antitumor effects in myeloma. Nat Med 2015;21:914-21.

[4] Turtle CJ, Riddell SR, Maloney DG. CD19-Targeted chimeric antigen receptor-modified T-cell immunotherapy for B-cell malignancies. Clin Pharmacol Ther 2016;100:252-8.

[5] Robbins PF, Dudley ME, Wunderlich J, El-Gamil M, Li YF, Zhou J, et al. Cutting edge: persistence of transferred lymphocyte clonotypes correlates with cancer regression in patients receiving cell transfer therapy. J Immunol 2004; 173:7125-30.

[6] Maude SL, Frey N, Shaw PA, Aplenc R, Barrett DM, Bunin $\mathrm{NJ}$, et al. Chimeric antigen receptor $\mathrm{T}$ cells for sustained remissions in leukemia. N Engl J Med 2014;371:1507-17.

[7] Zhou J, Shen X, Huang J, Hodes RJ, Rosenberg SA, Robbins PF. Telomere length of transferred lymphocytes correlates with in vivo persistence and tumor regression in melanoma patients receiving cell transfer therapy. J Immunol 2005;175:704652.

[8] Powell DJ Jr, Dudley ME, Robbins PF, Rosenberg SA. Transition of late-stage effector $\mathrm{T}$ cells to CD27+ CD28+ tumor-reactive effector memory $\mathrm{T}$ cells in humans after adoptive cell transfer therapy. Blood 2005;105:241-50.

[9] Kalos M, Levine BL, Porter DL, Katz S, Grupp SA, Bagg $A$, et al. T cells with chimeric antigen receptors have potent antitumor effects and can establish memory in patients with advanced leukemia. Sci Transl Med 2011;3:95ra73. doi:10.1126/scitranslmed.3002842.

[10] Louis CU, Savoldo B, Dotti G, Pule M, Yvon E, Myers GD, et al. Antitumor activity and long-term fate of chimeric antigen receptor-positive $\mathrm{T}$ cells in patients with neuroblastoma. Blood 2011;118:6050-6.

[11] Gattinoni L, Klebanoff CA, Palmer DC, Wrzesinski C, Kerstann K, Yu Z, et al. Acquisition of full effector function in vitro paradoxically impairs the in vivo antitumor efficacy of adoptively transferred CD8+ $\mathrm{T}$ cells. J Clin Invest 2005; 115:1616-26.

[12] Gattinoni L, Lugli E, Ji Y, Pos Z, Paulos CM, Quigley MF, et al. A human memory $\mathrm{T}$ cell subset with stem cell-like properties. Nat Med 2011;17:1290-7.

[13] Barrett DM, Singh N, Liu X, Jiang S, June CH, Grupp SA, et al. Relation of clinical culture method to T-cell memory status and efficacy in xenograft models of adoptive immunotherapy. Cytotherapy 2014;16:619-30.

[14] Sommermeyer D, Hudecek M, Kosasih PL, Gogishvili T, Maloney DG, Turtle CJ, et al. Chimeric antigen receptormodified $\mathrm{T}$ cells derived from defined CD8(+) and CD4(+) subsets confer superior antitumor reactivity in vivo. Leukemia 2016;30:492-500.

[15] Sallusto F, Geginat J, Lanzavecchia A. Central memory and effector memory $\mathrm{T}$ cell subsets: function, generation, and maintenance. Annu Rev Immunol 2004;22:745-63.

[16] Dudley ME, Rosenberg SA. Adoptive-cell-transfer therapy for the treatment of patients with cancer. Nat Rev Cancer 2003;3:666-75.

[17] Ho PC, Meeth KM, Tsui YC, Srivastava B, Bosenberg MW, Kaech SM. Immune-based antitumor effects of BRAF inhibitors rely on signaling by CD40L and IFNgamma. Cancer Res 2014;74:3205-17.

[18] Bos R, Sherman LA. CD4+ T-cell help in the tumor milieu is required for recruitment and cytolytic function of CD8+ T lymphocytes. Cancer Res 2010;70:8368-77.

[19] Janssen EM, Lemmens EE, Wolfe T, Christen U, von Herrath MG, Schoenberger SP. CD4+ T cells are required for secondary expansion and memory in CD8+ T lymphocytes. Nature 2003;421:852-6.

[20] Shedlock DJ, Shen H. Requirement for CD4 T cell help in generating functional CD8 $\mathrm{T}$ cell memory. Science 2003;300:337-9.

[21] Crompton JG, Sukumar M, Restifo NP. Uncoupling T-cell expansion from effector differentiation in cell-based immunotherapy. Immunol Rev 2014;257:264-76.

[22] Boyman O, Sprent J. The role of interleukin-2 during homeostasis and activation of the immune system. Nat Rev Immunol 2012;12:180-90.

[23] Shen X, Zhou J, Hathcock KS, Robbins P, Powell DJ Jr, Rosenberg SA, et al. Persistence of tumor infiltrating lymphocytes in adoptive immunotherapy correlates with telomere length. J Immunother 2007;30:123-9.

[24] Rochman Y, Spolski R, Leonard WJ. New insights into the regulation of $\mathrm{T}$ cells by gamma(c) family cytokines. Nat Rev Immunol 2009;9:480-90.

[25] Cieri N, Camisa B, Cocchiarella F, Forcato M, Oliveira G, Provasi E, et al. IL-7 and IL-15 instruct the generation of human memory stem $\mathrm{T}$ cells from naive precursors. Blood 2013;121:573-84.

[26] Gomez-Eerland R, Nuijen B, Heemskerk B, van Rooij N, van den Berg $\mathrm{JH}$, Beijnen $\mathrm{JH}$, et al. Manufacture of gene-modified human T-cells with a memory stem/central memory phenotype. Hum Gene Ther Methods 2014;25:27787.

[27] Gargett T, Brown MP. Different cytokine and stimulation conditions influence the expansion and immune phenotype of third-generation chimeric antigen receptor $\mathrm{T}$ cells specific for tumor antigen GD2. Cytotherapy 2015;17:487-95.

[28] Singh N, Perazzelli J, Grupp SA, Barrett DM. Early memory phenotypes drive $\mathrm{T}$ cell proliferation in patients with pediatric malignancies. Sci Transl Med 2016;8:320ra3.

[29] Hinrichs CS, Spolski R, Paulos CM, Gattinoni L, Kerstann KW, Palmer DC, et al. IL-2 and IL-21 confer opposing differentiation programs to CD8+ T cells for adoptive immunotherapy. Blood 2008;111:5326-33.

[30] Xu Y, Zhang M, Ramos CA, Durett A, Liu E, Dakhova O, et al. Closely related T-memory stem cells correlate with in vivo expansion of CAR.CD19-T cells and are preserved by IL-7 and IL-15. Blood 2014;123:3750-9.

[31] Gargett T, Yu W, Dotti G, Yvon ES, Christo SN, Hayball JD, et al. GD2-specific CAR T Cells Undergo Potent Activation and Deletion Following Antigen Encounter but can be Protected From Activation-induced Cell Death by PD-1 Blockade. Mol Ther 2016;24:1135-49.

[32] Sabatino M, Hu J, Sommariva M, Gautam S, Fellowes V, Hocker JD, et al. Generation of clinical-grade CD19specific CAR-modified CD8+ memory stem cells for the treatment of human B-cell malignancies. Blood 2016;128:51928.

[33] Karlsson H, Svensson E, Gigg C, Jarvius M, Olsson-Stromberg U, Savoldo B, et al. Evaluation of Intracellular Signaling Downstream Chimeric Antigen Receptors. PLoS ONE 2015;10:e0144787. doi:10.1371/journal.pone.0144787.

[34] Koponen JK, Kekarainen T, Heinonen SE, Laitinen A, Nystedt J, Laine J, et al. Umbilical cord blood-derived progenitor cells enhance muscle regeneration in mouse hindlimb ischemia model. Mol Ther 2007;15:2172-7. 
[35] R Core Team. R: a language and environment for statistical computing. Available from: https://www.R-project.org/ [Accessed 05.12.16].

[36] Mock U, Nickolay L, Philip B, Cheung GW, Zhan H, Johnston IC, et al. Automated manufacturing of chimeric antigen receptor $\mathrm{T}$ cells for adoptive immunotherapy using CliniMACS prodigy. Cytotherapy 2016;18:1002-11.

[37] Maus MV, Grupp SA, Porter DL, June CH. Antibodymodified T cells: CARs take the front seat for hematologic malignancies. Blood 2014;123:2625-35.

[38] Turtle CJ, Hanafi LA, Berger C, Gooley TA, Cherian S, Hudecek M, et al. CD19 CAR-T cells of defined CD4+:CD8+ composition in adult B cell ALL patients. J Clin Invest 2016;126:2123-38.

[39] Donia M, Junker N, Ellebaek E, Andersen MH, Straten PT, Svane IM. Characterization and comparison of 'standard' and 'young' tumour-infiltrating lymphocytes for adoptive cell therapy at a Danish translational research institution. Scand J Immunol 2012;75:157-67.
[40] Tumaini B, Lee DW, Lin T, Castiello L, Stroncek DF, Mackall C, et al. Simplified process for the production of anti-CD19-CAR-engineered $\mathrm{T}$ cells. Cytotherapy 2013;15:1406-15.

[41] Farber DL, Yudanin NA, Restifo NP. Human memory T cells: generation, compartmentalization and homeostasis. Nat Rev Immunol 2014;14:24-35.

[42] Parrot $T$, Allard M, Oger R, Benlalam H, Raingeard de la Bletiere D, Coutolleau A, et al. IL-9 promotes the survival and function of human melanoma-infiltrating CD4(+) CD8(+) double-positive T cells. Eur J Immunol 2016;46:1770-82.

\section{Appendix: Supplementary material}

Supplementary data to this article can be found online at doi:10.1016/j.jcyt.2017.03.067. 